\title{
Timing of nutrient depletion, diatom dominance and a lower-boundary estimate of export production for Irminger Basin, North Atlantic
}

\author{
Stephanie A. Henson ${ }^{1,2, *}$, Richard Sanders ${ }^{1}$, Claire Holeton ${ }^{1,3}{ }^{,}$John T. Allen ${ }^{1}$ \\ ${ }^{1}$ National Oceanography Centre, Southampton, European Way, Southampton SO14 3ZH, UK \\ ${ }^{2}$ Present address: School of Marine Sciences, 461D Aubert Hall, University of Maine, Orono, Maine 04469-5706, USA \\ ${ }^{3}$ Present address: Department of Plant Ecology, Uppsala University, Villavägen 14, 75236 Uppsala, Sweden
}

\begin{abstract}
During the North Atlantic spring bloom, a seasonal phytoplankton community succession takes place from diatoms to non-siliceous phytoplankton. Diatoms rely on silica to form their frustules and are out-competed by other species when silica becomes depleted. Diatoms are also expected to contribute significantly to export production in the North Atlantic. We suggest that a lower boundary to export production can be estimated as the component of total production that occurs between the start of the spring bloom and the time when silica becomes depleted. This method has been tested in the Irminger Basin, located between Greenland and Iceland, in the North Atlantic. A technique to estimate silica concentration from satellite-derived sea surface temperature and chlorophyll a concentration has been developed and used to determine silica concentration at high spatial and temporal resolution. This facilitates an estimation of the timing of silica depletion and thus the timing of the transition from a phytoplankton community dominated by diatoms to dominance by non-siliceous species. The timing of the initiation of the bloom, defined as a pronounced and sustained increase in biomass, is estimated from a Sea-viewing Wide Field-of-View Sensor (SeaWiFS)-derived chlorophyll a concentration. A lower-boundary estimate of export production is made and, additionally, estimates of the contribution to export production by diatoms and non-diatoms are made by considering silica-to-nitrate drawdown ratios. We estimate export production in this region to be $\sim 60 \mathrm{~g} \mathrm{C} \mathrm{m}^{-2} \mathrm{yr}^{-1}$, of which diatoms account for $\sim 65 \%$.
\end{abstract}

KEY WORDS: SeaWiFS - Silica depletion - Export production · Community composition · Spring bloom timing

Resale or republication not permitted without written consent of the publisher

\section{INTRODUCTION}

A major route for the transfer of carbon from the atmosphere to the ocean is the uptake of $\mathrm{CO}_{2}$ by phytoplankton and its subsequent removal from surface waters, i.e. the biological pump (Eppley \& Peterson 1979, Fasham 2003). As well as driving this biological pump, primary production forms the base of the marine food web and thus affects all trophic levels, including commercial fishing. Estimating the magnitude, seasonality and variability of primary production is therefore central to understanding the factors controling, and the strength of, the carbon pump. In terms of the global marine carbon cycle, only 1 component of total production is available for transfer to deep waters or higher trophic levels - this is termed export production (Eppley \& Peterson 1979).

Supply and depletion of nutrients in surface waters is an important factor in controlling phytoplankton populations. Production relies on a supply of the major nutrients nitrate, phosphate, silicate and additional trace elements such as iron. Outside the oligotrophic gyres, the end of the North Atlantic spring bloom is usually associated with nutrient depletion (e.g. Savidge et al. 1992), although in some cases grazing by zooplankton may bring the bloom to an end (e.g. Pon- 
daven et al. 1999). Estimating nutrient concentrations is fundamental to understanding planktonic ecosystems, but traditional shipboard measurements are not able to sample over wide areas or long time periods. The possibility of estimating nutrient concentration from remotely sensed parameters is therefore alluring.

Inverse relationships between sea surface temperature (SST) and the major inorganic nutrients (particularly nitrate) have been demonstrated and used to estimate surface nutrient concentration from remotely sensed SST (e.g. Sathyendranath et al. 1991, Minas \& Minas 1992, Chavez et al. 1996). These relationships occur because cold, nutrient-rich water present after winter-mixing becomes progressively warmer whilst nutrients are consumed by phytoplankton growth. However, as shown by Henson et al. (2003), these temperature-nitrate $(\mathrm{T}-\mathrm{N})$ relationships can have strong non-linear seasonal dependence due to the different time scales of nutrient depletion and surface heating during the spring growth season. This seasonality cautions against aggregating data from several different years and seasons to establish a $\mathrm{T}-\mathrm{N}$ relationship. From a study in the North Pacific, Goes et al. (1999, 2000) concluded that non-linearity in the $\mathrm{T}-\mathrm{N}$ relationship could be mitigated by including chlorophyll in a multiple regression of SST and nitrate.

The majority of published studies focus on nitrate, as historically there are more nitrate measurements available than other nutrient data. Additionally, the drawdown of nitrate during the spring bloom can be used to estimate new production. As defined by Dugdale \& Goering (1967), new production is that portion of total production driven by 'newly available nitrogen', supplied through convective mixing, mesoscale activity or atmospheric input. Late in the growth season, nutrients regenerated from organic material synthesised during the bloom are utilised in recycled production. However, in terms of the global carbon cycle, it is only the new production fraction of total production that is available for export to deep waters or higher trophic levels (Eppley \& Peterson 1979). More recently, the definition of new production has been restated as the drawdown of the limiting nutrient over the growth period (Aufdenkampe et al. 2002). Nitrate is not the only nutrient limiting growth. Different phytoplankton functional groups take up nutrients at different rates and ratios such that concentrations limiting to one phytoplankton group may not be limiting to another. For example, diatoms require silica to form their cell wall, and at reduced concentrations of silica a succession to other species that are not dependent on silica occurs (Egge \& Aksnes 1992, Brown et al. 2003). Iron has also been suggested as a limiting nutrient in the North Atlantic, both from in situ (Martin et al. 1993, Boye et al. 2003) and modelling studies (Kamykowski et al. 2002, Moore et al. 2004).
In many parts of the global ocean the seasonal cycle of export production is dominated by an annual phytoplankton spring bloom (Falkowski et al. 2000). The bloom is characterised by pronounced increases in plankton biomass and the removal of dissolved nutrients in surface waters. Diatoms often dominate the North Atlantic spring bloom, which is accompanied by high rates of nutrient consumption and primary production (Savidge et al. 1995). Diatoms are capable of growth rates which greatly outstrip those of nondiatom species (Furnas 1990), allowing them to reach bloom concentrations very quickly and establish dominance in community composition early in the growth season. Once silica is depleted, a seasonal community succession takes place: from diatoms in spring to smaller, non-siliceous flagellates and picoplankton in summer (e.g. Mitchell 1992, Barlow et al. 1993, Gregg et al. 2003). These later communities may rely on recycled nutrients for much of their production, but in a steady state system, recycled production does not contribute to export flux. As nitrate reducers capable of rapid transport of organic material to deep water, diatoms dominate export production in high latitudes (Dugdale et al. 1995). Unlike nitrate and phosphate, silica is not passed up the food chain to any degree, and its regeneration is not by organic degradation but by dissolution of opaline $\mathrm{SiO}_{2}$ (Broecker \& Peng 1982). Regeneration is expected to continue to greater depths than typically found for nitrate and phosphate. Thus, it is possible that silica, rather than nitrate, limits export production in diatom-dominated regions (Dugdale \& Wilkerson 1998).

There are 2 possible ways of estimating export production - through the drawdown of nutrients during the growth season, and from models based on satellite chlorophyll a concentration: From in situ data, the drawdown of nutrients during the spring bloom can be used to estimate new production. The amount of nitrate consumed by phytoplankton over the spring growth period can be converted into an estimate of new production in terms of carbon via the Redfield ratio (Redfield et al. 1963). By observing the depthintegrated seasonal decrease in nutrient concentrations, estimates of new production have been made in the North Atlantic by Campbell \& Aarup (1992), Garside \& Garside (1993), Henson et al. (2003) and Sanders et al. (2005). Satellite ocean colour data provides an alternative method for estimating export production. Falkowski et al. (1998) and Laws et al. (2000) both used Behrenfeld \& Falkowski (1997a) algorithm to estimate total primary production from ocean colourderived chlorophyll a. Various relationships were then used to convert from total to export production. Both studies used the Eppley \& Peterson (1979) empirical relationship between new and total production. Laws 
et al. (2000) also employed an SST against F-ratio regression and a food web model.

The Irminger Basin, situated between Greenland and Iceland, is thought to be a region of high export production. Satellite-based estimates suggest an annual mean export of $\sim 100$ to $150 \mathrm{~g} \mathrm{C} \mathrm{m}^{-2}$ (Falkowski et al. 1998, Laws et al. 2000), which is in contrast to new production estimates based on in situ measurements of nitrate drawdown, which range from $\sim 35$ to $60 \mathrm{~g} \mathrm{C} \mathrm{m}^{-2}$ (Henson et al. 2003, Sanders et al. 2005, Waniek et al. 2005). Currently, global estimates of primary and export production can only be made with sufficient spatial and temporal resolution using satellite databased methods. However, the accuracy of the globally derived satellite estimates by Falkowski et al. (1998) and Laws et al. (2000) have been questioned not only in the Irminger Basin, but also in other areas (e.g. Barbini et al. 2005, Neuer et al. 2002, Schlitzer 2002). This leads to large uncertainties in the contribution of phytoplankton production to the global carbon cycle and drawdown of $\mathrm{CO}_{2}$. This study aimed at an alternative way of estimating export production from satellite data by considering nutrient consumption.

In the North Atlantic, diatoms appear to dominate the phytoplankton community composition until silica

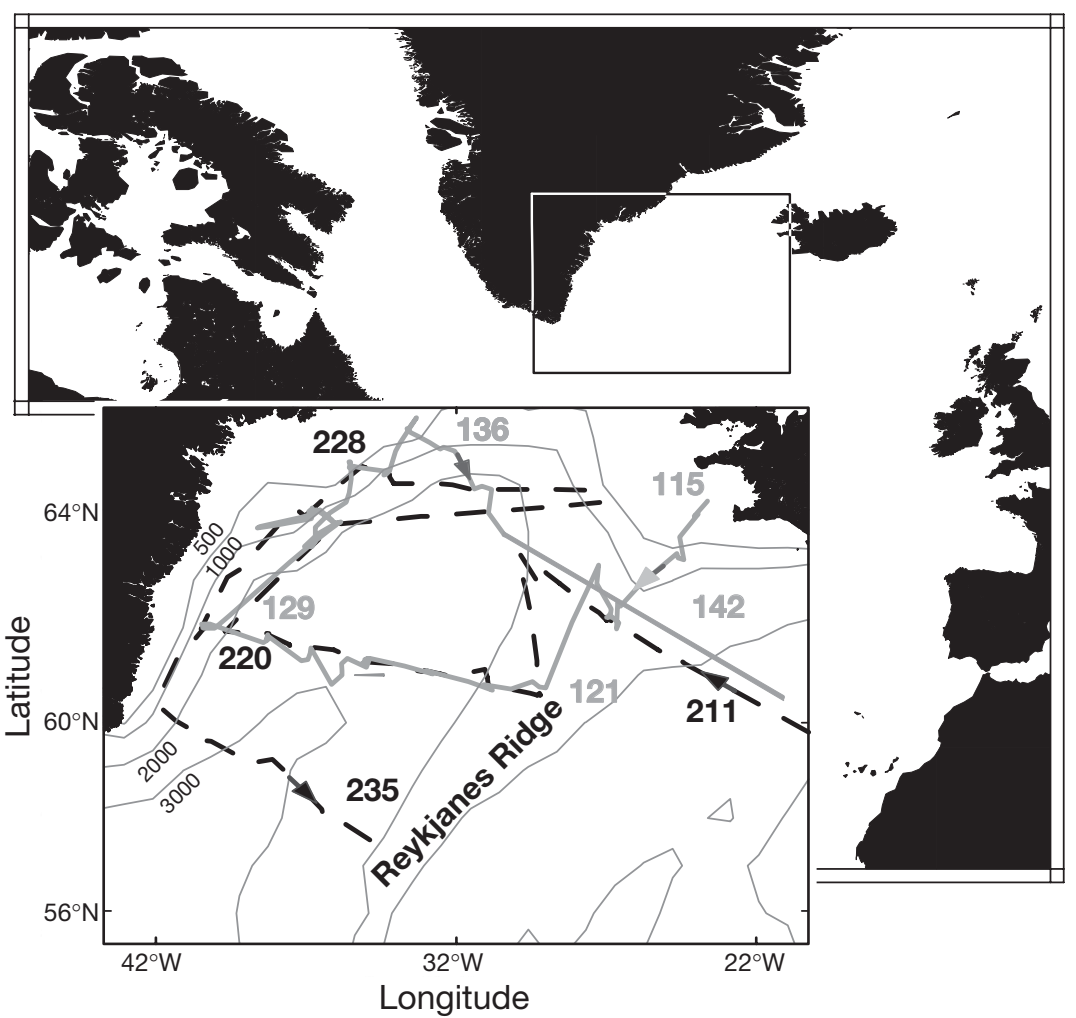

Fig. 1. Irminger Basin, showing its location in the North Atlantic, bathymetry (500, 1000, 2000 and $3000 \mathrm{~m})$ and location of Reykjanes Ridge. Tracks of marine productivity cruises and dates (day of year) of ship's transit on spring $(-)$ and summer $\left(--_{-}\right)$cruises. Arrows show direction of ship's movement is depleted (e.g. Barlow et al. 1993). The timing of silica depletion, and hence diatom dominance, is central to understanding the controls on the biological carbon pump. In this study, we used satellite data-based estimates of nitrate and silica concentration to examine the timing of nutrient depletion and infer its influence on species succession. We also calculated a lowerboundary estimate of export production based on the component of total production that occurs between the initiation of the spring bloom and the time when silica becomes depleted. Consideration of nutrient drawdown ratios also allowed an estimate of the relative contributions to export production by diatoms and non-diatoms.

\section{MATERIALS AND METHODS}

In situ data were collected on 4 cruises in the Irminger Basin during the UK NERC Marine Productivity programme (www.nerc.ac.uk/funding/thematics/marprod). The cruises took place in early winter (November and December 2001 and 2002), early spring (April and May 2002) and summer (July and August 2002). Surface samples for nutrients and chlorophyll were taken from the surface Niskin bottle of each CTD cast and, with the exception of the winter 2001 cruise, were taken every $4 \mathrm{~h}$ from the RRS 'Discovery's' continuous thermosalinograph outflow from an intake at a depth of $5 \mathrm{~m}$. Continuous underway SST data were also recorded. Fig. 1 shows the survey region with cruise tracks overlaid.

Nutrient samples were drawn into brand-new $40 \mathrm{ml}$ diluvials and immediately refrigerated at $4{ }^{\circ} \mathrm{C}$ until analysis, which commenced within $12 \mathrm{~h}$ of sampling. The concentration of nutrients was determined using a Skalar San Plus autoanalyser (Kirkwood 1995, Sanders \& Jickells 2000). Overall, the precision of the data from individual cruises was estimated to be better than $\pm 0.18 \mu \mathrm{mol} \mathrm{l}^{-1}$ for nitrate and $\pm 0.15 \mu \mathrm{mol} \mathrm{l}^{-1}$ for silicate $(1 \%$ of top standard for nitrate and $0.5 \%$ for silicate).

Samples for chlorophyll analysis were filtered through $25 \mathrm{~mm}$ Whatman GF/F filters using a positive-pressure filtration unit. The filters were then placed in amber glass vials containing $10 \mathrm{ml}$ of $90 \%$ acetone and immediately stored in the dark at $5^{\circ} \mathrm{C}$ for $24 \mathrm{~h}$ to extract the chlorophyll. Samples were 
warmed to room temperature before the fluorescence was measured using a Turner Designs fluorometer (TD700). Chlorophyll standard solutions (from SigmaAldrich) covering the expected chlorophyll range were used for calibration of the fluorometer before each set of samples were analysed. The chlorophyll concentrations were calculated from the light absorption measured at 750, 664, 647 and $630 \mathrm{~nm}$ in a Cecil spectrophotometer, using the equations of Jeffrey \& Humphrey (1975).

Samples for taxonomic identification of phytoplankton were typically taken at the surface, at the chlorophyll maximum and at $100 \mathrm{~m}$ depth. Duplicates of $100 \mathrm{ml}$ samples at each depth were preserved with 1\% Lugol's solution and $2 \%$ buffered formalin. Taxa counts were performed by inverted microscopy. Biovolume was calculated for each protist plankton species (Kovala \& Larrance 1966) and then converted to carbon biomass following carbon to biovolume relationships described for diatoms (Menden-Deuer \& Lessard 2000) and non-diatom protist plankton (Strathmann 1967).

AVHRR (advanced very high-resolution radiometry) SST data at $0.5^{\circ}$, daily resolution were downloaded
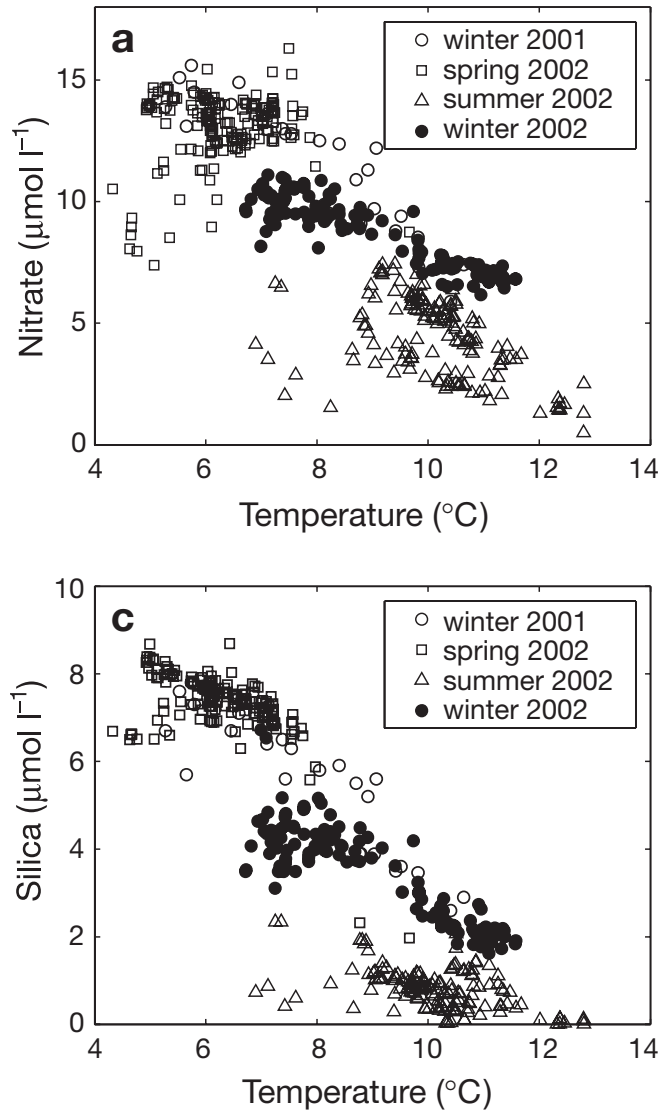

through the NASA JPL Physical Oceanography Distributed Active Archive Centre via http://podaac-esip. jpl.nasa.gov/poet/. Sea-viewing Wide Field-of-View Sensor (SeaWiFS) chlorophyll a (hereafter chl a) data at $9 \mathrm{~km}$, daily resolution were downloaded via the NASA Distributed Active Archive Centre at http:// oceancolor.gsfc.nasa.gov/ftp.html. The data were resampled to a $0.5^{\circ}$ grid to coincide with the SST data.

\section{RESULTS}

\section{Remote estimation of nutrients}

Temperature is plotted against nitrate, divided into seasons, for the Irminger Basin in Fig. 2a (redrawn from Henson et al. 2003). Although the data from the winter cruises show a linear relationship, the spring and summer data exhibit a large amount of scatter. This seasonal non-linearity arises because in spring and summer nitrate removal occurs at a different rate from heating. As described by Henson et al. (2003), winter, wind-driven cooling and deep convective
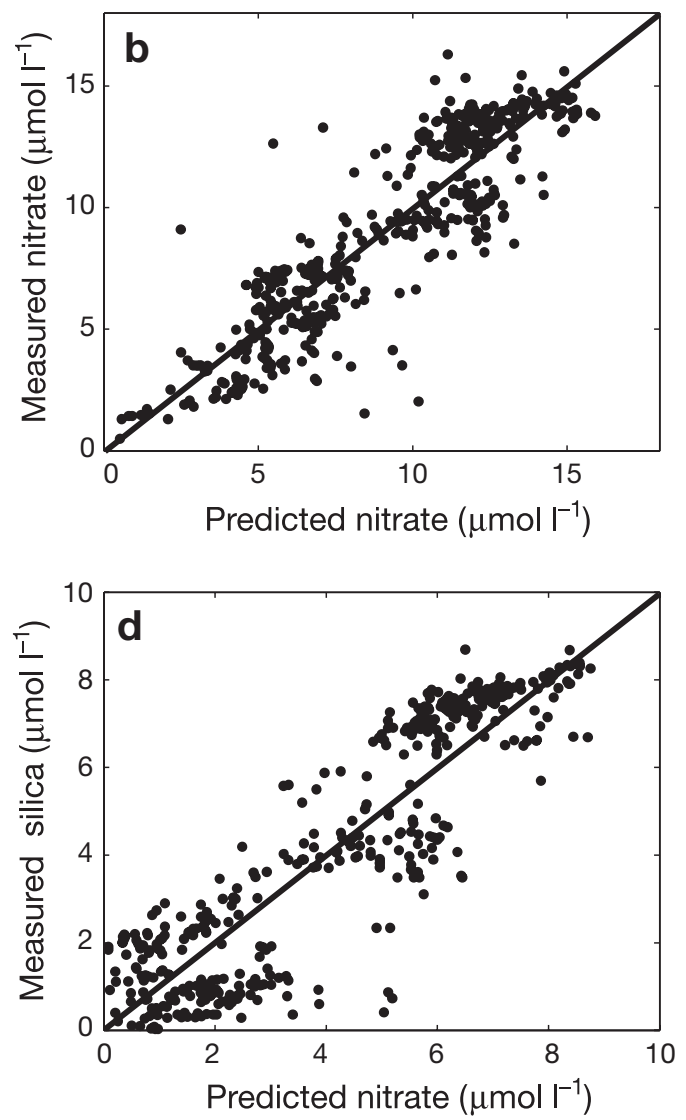

Fig. 2. (a, c) Nitrate and silica concentrations respectively as a function of in situ temperature during cruises in 2001 and 2002. (a) redrawn from Henson et al. 2003. (b, d) Concentrations of (b) nitrate and (d) silica predicted from multiple regression of nutrient with sea surface temperature (SST) and chlorophyll versus concentrations measured in situ; 1:1 line is plotted 
mixing results in low surface temperatures and high concentrations of nutrients. Biological utilisation of nutrients is minimal due to poor light conditions and continual mixing. In spring, increasing light levels and restratification due to surface heating result in the onset of production and the rapid consumption of nutrients. In post-bloom summer, nutrients have been stripped out of the surface waters by the phytoplankton and SST is at its peak. As solar heating declines during autumn and early winter, overturning begins and cold, nutrient-rich water is brought to the surface, but the conditions are not amenable to phytoplankton growth and the nutrients are not consumed. Therefore, this is the only time of year that a linear SST-nitrate relationship can be expected. At all other times of year, the different rates of heating and nitrate consumption prevents SST from varying linearly with surface nitrate.

Goes et al. (2000) suggested including satellitederived chl a data in the regression to allow for the biological uptake of nitrate. A multiple regression of SST and chl a against in situ nitrate in the Irminger Basin was performed. Fig. 2b shows a scatter plot of in situ against estimated nitrate. The regression is highly statistically significant $\left(\mathrm{p}<0.001, \mathrm{n}=468, \mathrm{RMSE}=1.77 \mu \mathrm{mol} \mathrm{l^{-1 }}\right)$ with correlation coefficient $\mathrm{r}^{2}=0.80$. The equation relating nitrate to $\mathrm{chl} a$ and SST is derived as:

$$
\mathrm{N}=25.33-1.78 \cdot \mathrm{SST}-1.84 \cdot \mathrm{chl} a
$$

The errors on the regression coefficients are \pm 0.37 , 0.04 and 0.12 respectively. This results in an error in estimated nitrate concentrations of $\sim 10 \%$. Eq. (1) is different from the relationship derived by Goes et al. (2000) for the North Pacific. This is to be expected, as each oceanographic region has differing temperature and nutrient conditions. As noted by Sathyendranath et al. (1991), a different $\mathrm{T}-\mathrm{N}$ relationship may need to be derived for each oceanic biogeographic province.

Although T-N relationships have been reported on several occasions, the relationship between temperature and silica has been far less widely investigated (Kamykowski et al. 2002). The seasonal dependence of the temperature-silica ( $\mathrm{T}-\mathrm{Si}$ ) relationship has not been considered. SST is plotted against silica concentration in Fig. 2c. The T-Si relationship has a different seasonal dependence from the $\mathrm{T}-\mathrm{N}$ relationship. In particular, the summertime silica concentration is relatively insensitive to SST. Fig. 2d shows a scatter plot of measured silica against silica predicted from SST and chl a. The equation relating silica concentration to SST and chl $a$ is derived as:

$$
\mathrm{Si}=15.51-1.33 \cdot \mathrm{SST}-0.57 \cdot \mathrm{chl} a
$$

Inclusion of chlorophyll results in a correlation of $\mathrm{r}^{2}=0.83\left(\mathrm{p}<0.001, \mathrm{n}=468, \mathrm{RMSE}=1.32 \mu \mathrm{mol} \mathrm{l}^{-1}\right)$. The errors on the regression coefficients are \pm 0.28 ,
0.03 and 0.09 respectively. This results in an error in estimated silica concentrations of $\sim 15 \%$. The summer silica concentration is relatively insensitive to the inclusion of chl $a$, although the addition of the chl $a$ term to the regression improves the linearity in the other seasons. Silica is below $\sim 2 \mu \mathrm{mol} \mathrm{l}^{-1}$ at all temperatures in the summer. The regression equation implies that if SST and chl a are decreasing, silica is expected to increase; however, this does not occur during summer, hence the overestimation in predicted silica. This suggests that in summer, during events which mix up cold water, silica is being consumed before it reaches the surface waters, indicating the possible presence of a sub-surface siliceous plankton community (e.g. Parslow et al. 2001). The same issue does not arise in the $\mathrm{T}-\mathrm{N}$ relationship, suggesting that nitrate does not become limiting, allowing non-siliceous plankton to remain in the well-lit surface waters. Despite this, only approximately $15 \%$ of the predicted summertime silica concentrations fall outside 2 standard deviations from the regression best-fit line.

It is interesting to note that if in situ salinity is introduced as an additional term in Eqs. (1) and (2), the predictive power of the relationships is improved even further $\left(r^{2}>0.87\right)$. This suggests that some of the variability not explained by SST or chl a arises from changes in the water mass composition in the Irminger Basin. At the present time, salinity cannot be measured remotely, and is therefore not included in the analysis presented in this paper. However, the launch of the ESA Soil Moisture and Ocean Salinity sensor scheduled for early 2007 (Berger et al.

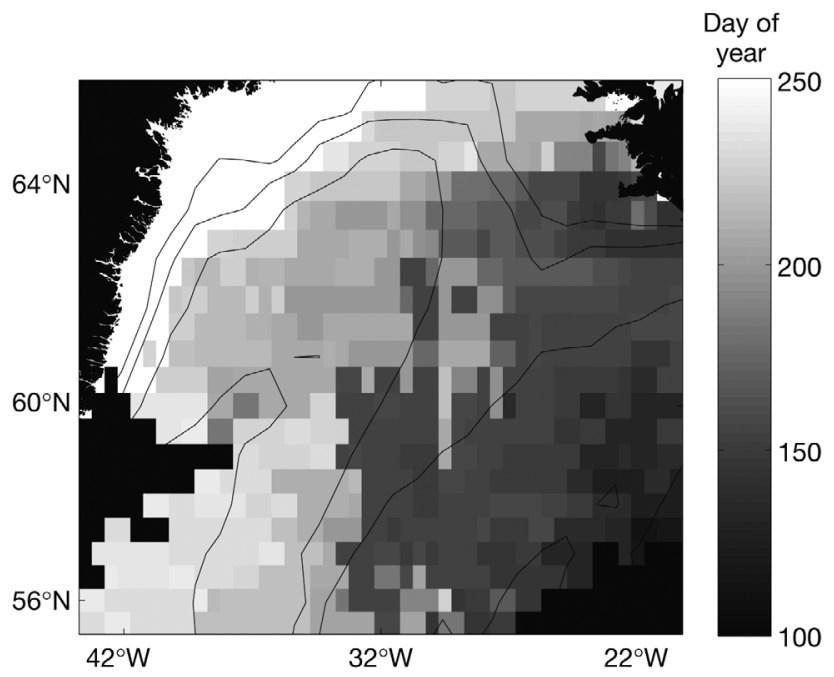

Fig. 3. Day of year on which silica first falls below $2 \mu \mathrm{mol} \mathrm{l}^{-1}$. Silica estimated from satellite SST and chlorophyll. In black patch near SE tip of Greenland, silica does not become depleted. White areas: insufficient data to define a relationship 

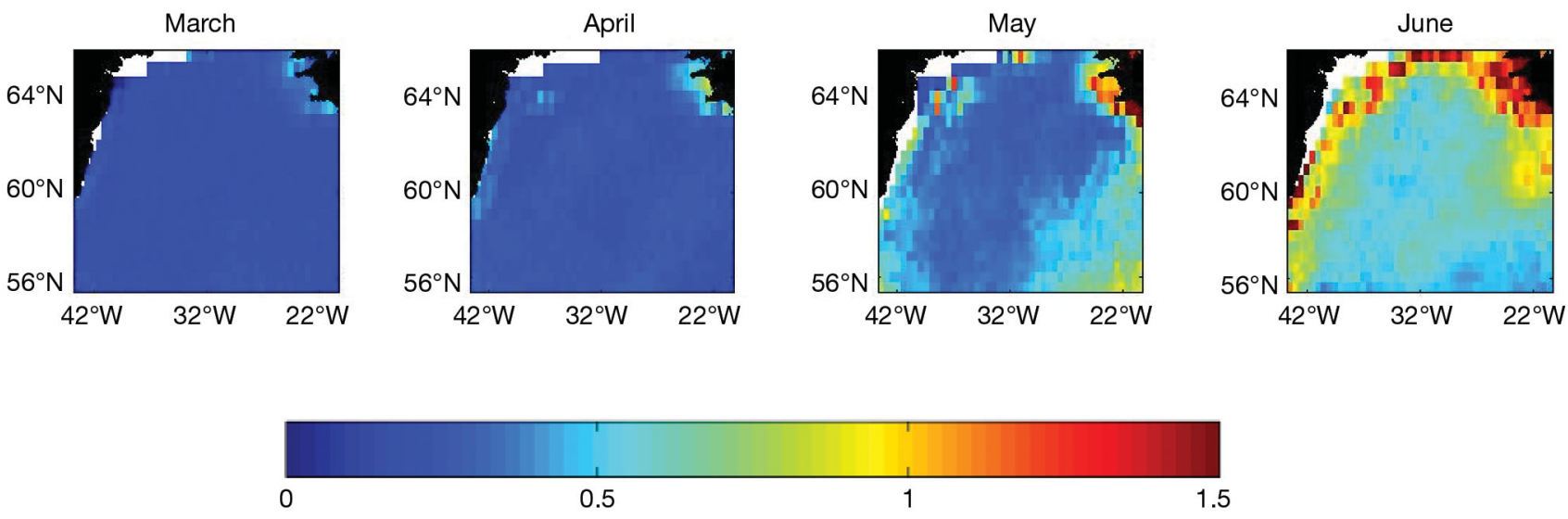

Chlorophyll a $\left(\mathrm{mg} \mathrm{m}^{-3}\right)$
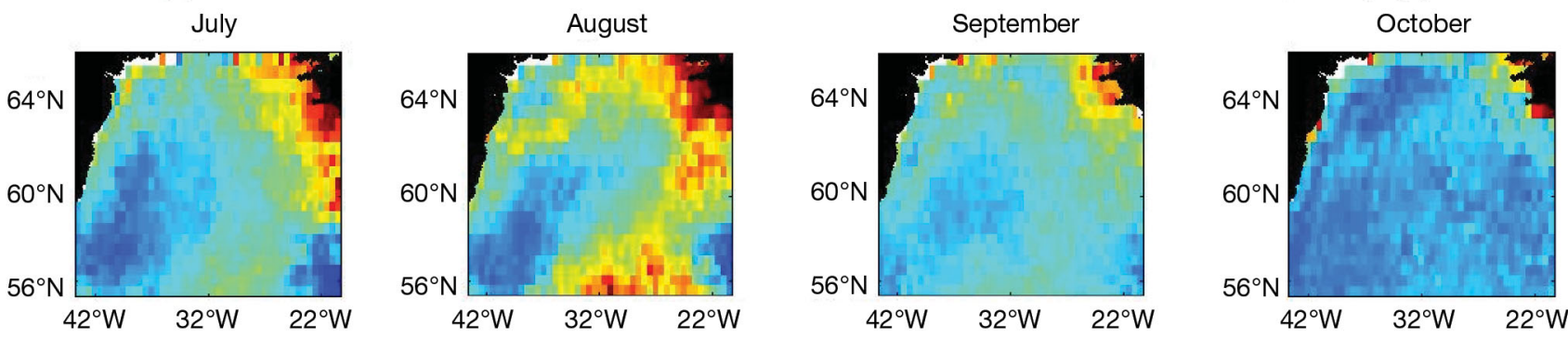

Fig. 4. Monthly median SeaWiFS chlorophyll a for March to October 2002

2002) promises the possibility of further advances in estimating nutrients at high spatial and temporal resolution using satellite data. In the following analysis, estimates of nitrate and silica at $0.5^{\circ}$, daily resolution were made from satellite SST (AVHRR) and SeaWiFS chl a using Eqs. (1) and (2).

\section{Nutrient depletion}

The concentration at which a nutrient becomes limiting to growth can be difficult to define without in situ uptake experiments, which were not conducted during the cruise programme. However, the daily maps of satellite-derived surface nutrient concentrations can be used to estimate the annual minimum concentration. In the Irminger Basin, nitrate is plentiful yearround, with a basin-wide mean annual minimum concentration of $\sim 3 \mu \mathrm{mol} \mathrm{l}^{-1}$, although some parts of the basin reach a minimum of $\sim 1 \mathrm{mmol} \mathrm{l}^{-1}$ (Fig. 2a). Phosphate also remains undepleted in the Irminger Basin with a minimum of $\sim 0.3 \mu \mathrm{mol} \mathrm{l^{-1 }}$ (cruise data from Brierley et al. 2003). These relatively high concentrations are unlikely to be limiting to growth (e.g. Tyrell 1999). WOCE atlas data suggest that these nutrient conditions are not unique to 2002, the year of the cruise programme, but are the norm in the Irminger Basin (Conkright et al. 2002).
In large parts of the basin, the remotely sensed annual minimum concentration of silica drops to below, $\sim 2 \mu \mathrm{mol} \mathrm{l}^{-1}$ (also seen in the in situ data in Fig. 2c). The threshold of silica concentration at which diatoms are out-competed by non-siliceous plankton has been suggested as $2 \mu \mathrm{mol} \mathrm{l}^{-1}$ by Egge \& Aksnes (1992). Brown et al. (2003) also suggested $2 \mu \mathrm{mol} \mathrm{l}^{-1}$ on the basis of an in situ study of the Iceland Basin. Although silica is still consumed by a remnant diatom population at concentrations below $2 \mu \mathrm{mol} \mathrm{l} \mathrm{l}^{-1}$ (Fig. 2c), they are no longer able to out-compete non-siliceous functional groups. We choose, therefore, to use a silica concentration of $2 \mu \mathrm{mol} \mathrm{l}^{-1}$ to define the transition from dominance of the species composition by diatoms to dominance by other functional groups. An estimate of the timing of diatom dominance can thus be made from consideration of the timing of silica consumption. Fig. 3 shows the day of the year on which silica (derived from the satellite data as discussed above) first falls below $2 \mu_{\mathrm{mol}} \mathrm{l}^{-1}$ in the Irminger Basin. Silica becomes depleted across most of the basin, starting earliest east of the Reykjanes Ridge in early May. The Reykjanes Ridge itself experiences silica concentrations below $2 \mu \mathrm{mol} \mathrm{l}^{-1}$ in late May and early June, with the central basin following in July to August. White pixels along the East Greenland coast mark areas where the regression breaks down. This is a region where the cold, fresh, meltwater run-off promotes stratification 
early in spring and the growth of dense blooms of Phaeocystis sp. (Waniek et al. 2005). The unusual hydrographic properties of the coastal region suggest that a separate relationship is required. Unfortunately insufficient data were collected on the East Greenland coast to establish such a relationship. For the rest of the basin we suggest that the map of timing of silica depletion in Fig. 3 represents the timing of the transition from diatom dominance of the community composition to dominance by other non-siliceous species.

\section{Timing of bloom}

During the spring Marine Productivity cruise (April and May), the magnitude of biological activity typically associated with a spring bloom was not observed, with the exception of a dense Phaeocystis sp. bloom on the NE Greenland shelf (Waniek et al. 2005). During most of the cruise in late April and early May, diatoms were not observed at bloom concentrations, with the exception of the Reykjanes Ridge at the end of the cruise in mid-May, where the abundance of diatoms had increased substantially (see cruise track in Fig. 1). When the ship returned to the Irminger Basin in August, chlorophyll was elevated relative to winter levels, but was not at bloom concentrations. In terms of contribution to total carbon biomass, diatoms did not dominate the community composition during either cruise. Although a diatom bloom was not directly observed in the majority of the basin during the Marine Productivity cruises, a large quantity of silica was consumed during the growth season (from $\sim 10$ to $<2 \mu \mathrm{mol} \mathrm{l}{ }^{-1}$; Sanders et al. 2005). This suggests that diatoms had been a considerable component of the spring phytoplankton bloom community.

Satellite chlorophyll data can be used to estimate biomass and timing of phytoplankton growth between the 2 cruises. Although the 2 cruises did not observe bloom conditions, a bloom did occur in the Irminger Basin in 2002. Monthly median SeaWiFS chl a maps for March to October 2002 are shown in Fig. 4 (the median, rather than mean, is used as SeaWiFS chla is log-normally distributed, and so more accurately represented by the median; Campbell 1995). Fig. 4 shows that chl a concentration was $\sim 0.3 \mathrm{mg} \mathrm{m}^{-3}$ throughout March and April, except on the Iceland Shelf, where it was $\sim 0.5 \mathrm{mg} \mathrm{m}^{-3}$. During May, chl a started to increase around the edges of the basin reaching $\sim 0.5 \mathrm{mg} \mathrm{m}^{-3}$. By June, the whole basin was experiencing elevated chl a concentrations, with $\sim 0.5 \mathrm{mg} \mathrm{m}^{-3}$ in the central basin and $\sim 1 \mathrm{mg} \mathrm{m}^{-3}$ in the coastal regions. In July, chl a started to decline in the central basin although it remained high around the coast. During August, chl a increased again over the southern Reykjanes Ridge and northern basin to $\sim 1 \mathrm{mg}$ $\mathrm{m}^{-3}$. During September and October, chl a concentration decreased towards winter levels again. (Note that the chl a concentrations in Fig. 4 appear low because the monthly composites blur shorter timescale events; nevertheless the general seasonal cycle of chl $a$ is well-represented.) Comparison of these maps to the timing of the cruises shown in Fig. 1 suggests that the peak bloom biomass occurred between the spring and summer cruises.

The daily maps of chl a allow the timing of the initiation of the spring bloom to be determined. A bloom was defined by Longhurst (1998) as a large increase in biomass above normal conditions. Siegel et al. (2002) defined the start of a bloom as the day when chl a first rises $5 \%$ above the annual median value. Estimation of the start of the bloom was initially made using Siegel et al.'s (2002) method, however visual inspection of chl a time series at randomly selected pixels in the basin suggested that this method placed the start of the bloom $\sim 2$ wk too early. The method was detecting brief pulses of increased chl $a$ which occurred prior to the massive increase in biomass indicative of a bloom. A requirement that the elevated chl a levels must persist for at least $3 \mathrm{~d}$ was found to correctly detect the start of the main spring bloom. This eliminated transient events which may result in a brief increase in chl a that quickly recedes again because conditions are not yet suitable for a full spring bloom to develop.

Fig. 5 shows the start date (in days of the year) of the spring bloom in 2002 estimated from daily SeaWiFS chl a data. The bloom started earliest around the edges of the basin (early May) and spread towards the centre of the basin over the following $3 \mathrm{wk}$. The timing of the bloom estimated by this method matches

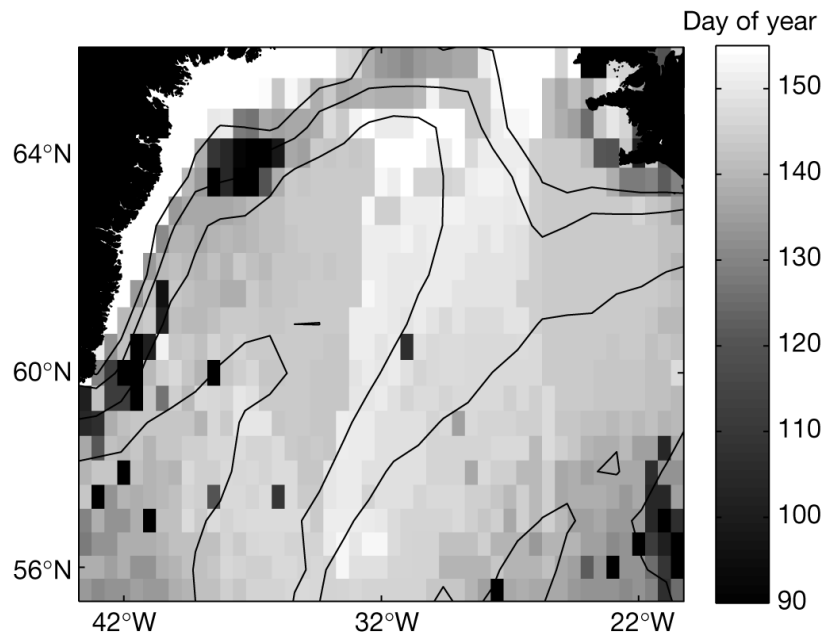

Fig. 5. Start date of spring bloom in 2002 estimated from daily SeaWiFS chlorophyll $a$ as first day when chlorophyll a rises $5 \%$ above annual median and remained elevated for at least 3 consecutive days 


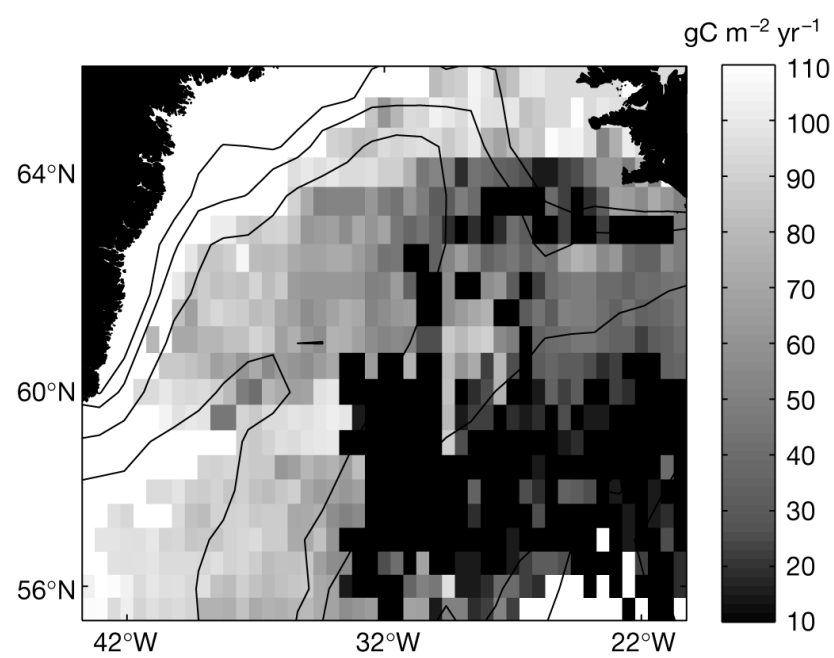

Fig. 6. Lower-boundary estimate of export production in 2002 based on the component of total production between start of bloom (Fig. 5) and day on which silica first fell below $2 \mu \mathrm{mol}$ $\mathrm{l}^{-1}$ (Fig. 3). White areas along Greenland coast: no estimate made because of lack of adequate silica-concentration estimate (see 'Results - Nutrient depletion')

well with the progression of the bloom in the monthly median maps (Fig. 4). Note that the lack of data along the NE Greenland coast in Figs. 4 \& 5 is due to seasonal ice cover and persistent cloud.

\section{Export estimate}

A lower-boundary estimate of export production can now be made by assuming that export production is the portion of total production which occurs between the start of the bloom and the time when silica concentrations are so low that diatoms are out-competed by other species. This accounts for all production by diatoms and non-siliceous plankton until silica is depleted. Total primary production was calculated using the vertically generalised production model (VGPM) of Behrenfeld \& Falkowski (1997a). The model requires as inputs satellite measurements of surface chlorophyll concentration, SST, daily mean photosynthetically available radiation and daily photoperiod. The model consists of a temperature-dependent algorithm to estimate $P^{B}{ }_{\text {opt }}$, the maximum carbon fixation rate within a water column, and irradiance-dependent terms in empirical relationships between satellite chl $a$ and euphotic depth and chlorophyll concentration at $P^{B}{ }_{\text {opt }}$.

Total production was calculated daily for 2002 at each pixel of the satellite data. Export production was estimated as that portion of the daily total production which occurred between the start of the bloom and the day when silica first droped below $2 \mu \mathrm{mol} \mathrm{l}^{-1}$ (as calculated for Figs. 5 \& 3 respectively). The primary production during this period i.e. our lower-boundary

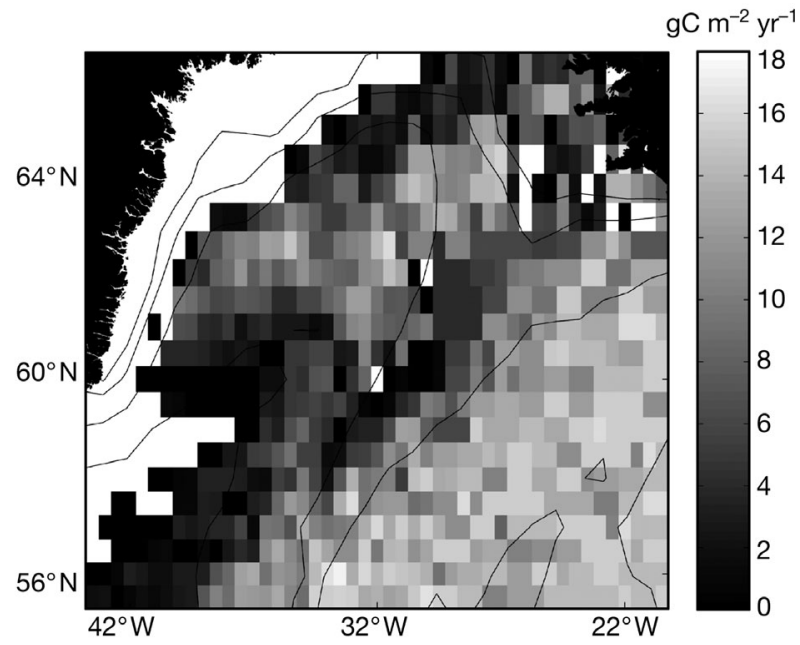

Fig. 7. Additional new production occurring after silica has been depleted, calculated as additional nitrate consumed, and converted to carbon units using the Redfield ratio (Redfield et al. 1963). White areas as in Fig. 6

estimate of the export production is shown for 2002 in Fig. 6. In the central basin export production was estimated at $\sim 40-60 \mathrm{~g} \mathrm{C} \mathrm{m}^{-2} \mathrm{yr}^{-1}$, occasionally rising as high as $\sim 80 \mathrm{~g} \mathrm{C} \mathrm{m}^{-2} \mathrm{yr}^{-1}$. East of the Reykjanes Ridge export was lower, at $\sim 30 \mathrm{~g} \mathrm{C} \mathrm{m}^{-2} \mathrm{yr}^{-1}$. The average basin-wide export production estimate was $\sim 40 \mathrm{~g} \mathrm{C} \mathrm{m}^{-2} \mathrm{yr}^{-1}$. This is comparable to in situ estimates based on nitrate drawdown, which ranged from $\sim 35$ to $60 \mathrm{~g} \mathrm{C} \mathrm{m}^{-2} \mathrm{yr}^{-1}$ (Henson et al. 2003, Sanders et al. 2005, Waniek et al. 2005).

There are 2 potential sources of numerical error in the export production estimate: firstly from the satellite-based estimates of timing of silica depletion and the start of the bloom, and secondly from the estimation of total production using Behrenfeld \& Falkowski's (1997a) algorithm. Errors in the latter have been examined by Behrenfeld \& Falkowski (1997b), with the general conclusion that the estimates of primary production that the algorithm produces for the northern North Atlantic are not biased either high or low relative to the global data set. We therefore focus on the errors arising from the novel aspects of our method. At a silica concentration of $2 \mu \mathrm{mol} \mathrm{l}^{-1}$ the error in the satellite-based estimate is $\pm 0.3 \mu \mathrm{mol} \mathrm{l^{-1 }}$. Based on the average rate at which silica is drawn down $(\sim 0.1 \mu \mathrm{mol}$ $\mathrm{d}^{-1}$ ), this results in an error in the timing of silica depletion of $\pm 3 \mathrm{~d}$. The error in the timing of the start of the bloom, based on a typical SeaWiFS chl a error of $\pm 30 \%$ (Hooker \& McClain 2000) and the rate at which chl $a$ increases, is $\pm 4 \mathrm{~d}$. Together, these errors result in a basin-wide mean error for the export production estimate of $\sim 20 \%$.

Whilst our estimate of export production is comparable to those made using in situ data, it is considerably lower than those estimates made by applying an 
export production algorithm directly to total production calculated from satellite chl a ( 100 to $150 \mathrm{~g} \mathrm{C}$ $\mathrm{m}^{-2} \mathrm{yr}^{-1}$; Falkowski et al. 1998, Laws et al. 2000). What causes this discrepancy in the estimates of export production? The estimates in this study and in Falkowski et al. (1998) and Laws et al. (2000) are all based on the primary production algorithm of Behrenfeld \& Falkowski (1997a), and yet they differ by a factor of 2 . The discrepancy may arise from interannual differences in the amount of export production between 1998 and 2003, the period of this study, and the years for which Falkowski et al. (1998) and Laws et al. (2000) made their estimates. Falkowski et al. (1998) used monthly mean coastal zone color scanner (CZCS) data from 1978 to 1986, whilst Laws et al. (2000) used monthly mean SeaWiFS data from October 1997 to September 1998. The estimates of Falkowski et al. (1998) and Laws et al. (2000) do not overlap in time with the estimates made here and, although interannual variability in export production will occur, it is unlikely to be on the order of a factor of 2. It is also possible that Behrenfeld \& Falkowski's (1997a) algorithm to estimate total production from chl $a$ is not correctly parameterised for the Irminger Basin. Their model consists of a series of empirical relationships between vertical distribution of biomass and chl $a$, SST etc., which were defined by in situ measurements. The productivity model was developed from a database of ${ }^{14} \mathrm{C}$ measurements, mostly made on the seaboard of the NE USA. It may be that the productivity algorithm is inaccurate in regions for which it was not explicitly parameterised, such as the Irminger Basin. Given a sufficiently large database of in situ measurements, the algorithm could be tailored to individual oceanic provinces, but unfortunately many regions of the ocean lack suitable coverage. Estimates of primary and export production derived from a single, globally applied algorithm may be inaccurate, and a regional approach is likely to yield improved estimates.

\section{DISCUSSION}

The described method of estimating export production provides only a lower boundary, as there are some additional potential sources it does not account for. Any supply of new nutrients during summer by storms or mesoscale activity, or any production that occurs as a result of a subsurface chlorophyll maximum is not accounted for. The method also assumes that little new production occurs prior to the spring bloom. Diatoms are likely to be the first species to exploit the vernal shallowing of the mixed layer. During the winter months, phytoplankton concentrations are at an annual minimum due to deep convective mixing, but a small population must survive the winter to seed the subsequent spring bloom (Huisman et al. 1999, Backhaus et al. 2003). The drawdown of nutrients between the winter and spring Marine Productivity cruises could give an estimate of the production taking place during winter. However, the surface nutrient concentrations were lower in winter than in spring, indicating that the 'winter' cruises actually took place in late autumn, prior to the onset of convective mixing. An alternative method was used by Sanders et al. (2005) to estimate the winter nitrate concentration. The $\mathrm{O}_{2}$ nitrate slope method of Koeve (2001) was employed to estimate the nitrate drawdown, and thus new production, prior to the spring marine productivity cruise. The estimated winter nitrate concentration was found to be similar to the observed spring concentrations. On this basis Sanders et al. (2005) concluded that no new production occurred in the Irminger Basin prior to the spring cruise in April and May. A further check to determine if any new production may have occurred prior to the bloom can be performed using the satellitebased estimates of nutrient concentration. The nitrate concentration on the initial day of the bloom was estimated from coincident satellite SST and chl $a$. Nitrate concentrations thus estimated were similar to the winter value estimated by Sanders et al. (2005), thus little new production is expected to occur prior to the spring bloom.

Our method for determining a lower bound of export production requires that diatoms contribute significantly to export, so that once silica depletion occurs and diatom dominance ends, the majority of export also ceases. The importance of diatoms to export production was inferred by Brzezinski et al. (1998), who suggested that if the ratio of nitrate to silicate drawdown is similar to the silica to nitrate molar ratio in nutrient-replete diatoms $(\sim 1)$, then diatoms are taking up an amount of nitrate equal to the total new production of the system. The average nitrate-to-silicate drawdown ratio in the Irminger Basin is 1.17 (Sanders et al. 2005). This is close to the ratio of Brzezinski et al. (1998), and so suggests that in the Irminger Basin diatoms are likely to be responsible for the majority of export production, until they become limited by silica depletion.

Once silica becomes limiting to diatom growth, it might be expected that new production by nonsiliceous phytoplankton would continue until all remaining nitrate has been consumed. However, this is not the case, and during the summer cruise nitrate concentrations of several $\mu \mathrm{mol} \mathrm{l}^{-1}$ were observed, although silica was depleted (Henson et al. 2003, Sanders et al. 2005). Henson et al. (2003) demonstrated, on the basis of $\mathrm{T}-\mathrm{N}$ relationships, that the majority of nitrate consumption occurs before SST 
reaches $6^{\circ} \mathrm{C}$. Once nitrate consumption ceases, any subsequent production must rely on recycled forms of nitrogen. According to satellite images of SST, a temperature of $6^{\circ} \mathrm{C}$ is reached in mid-May over the Reykjanes Ridge and by July in the central basin (data not shown), suggesting that a transition from export to recycled production occurs around this time. The monthly maps of chl a in Fig. 4 show that chlorophyll remains elevated above winter levels throughout the summer, indicating that production continues without consumption of new nitrate, and is therefore relying on recycled nutrients. Certainly, by the time of the summer Marine Productivity cruise in August, carbon biomass and primary production were dominated by the $<10 \mu \mathrm{m}$ size fraction, indicative of small, recycling producers (Astoreca 2003). As nitrate does not become depleted during the Irminger Basin spring bloom, silica is expected to be limiting the bloom, and hence export production.

The method accounts for export production by diatoms and non-siliceous plankton prior to silica depletion, but it assumes that there is little new production by non-siliceous plankton after silica has been depleted. As the productive season progresses, recycled forms of nitrogen, such as ammonia or urea, become available from the breakdown of organic material and excretion. Recycled nitrogen is preferentially taken up by plankton, as its assimilation requires lower energetic costs than nitrate assimilation (Syrett 1981), and ammonium concentrations $>1 \mu \mathrm{mol} \mathrm{l}^{-1}$ can inhibit nitrate uptake by phytoplankton (Wheeler \& Kokkinakis 1990). Some taxonomic groups are able to increase ammonium uptake at higher concentrations to a much greater extent than diatoms (Tungaraza et al. 2003). However, although the non-siliceous species which dominate later in the growth season are expected to preferentially take up recycled forms of nitrogen, it is possible that they also consume new nitrogen, thus contributing to export production.

Once nitrate reaches its minimum annual value, all further production must rely on recycled forms of nitrogen. The quantity of nitrate consumed after silica has been depleted and until nitrate reaches its minimum value can be estimated from the satellite-derived nitrate concentrations. To convert the nitrate consumed to new production, the surface nitrate must be integrated over the mixed-layer depth and converted to carbon using a Redfield ratio of 6.6 (Redfield et al. 1963). A mean summer (June and July) mixed-layer depth of $30 \mathrm{~m}$ was estimated from Argo float data (http://argo.jcommops.org). The additional new production occurring after silica depletion is shown in Fig. 7. To the west of the Reykjanes Ridge very little production $\left(\sim 5 \mathrm{~g} \mathrm{C} \mathrm{m}^{-2} \mathrm{yr}^{-1}\right)$ occurs after silica depletion, whilst to the east of the ridge there is an extra $\sim 15 \mathrm{~g} \mathrm{C} \mathrm{m}^{-2} \mathrm{yr}^{-1}$. This represents an additional contribution to export production after silica depletion (and hence by non-siliceous phytoplankton) of $~ 10 \%$ of the original export production estimate to the west of the ridge and $\sim 50 \%$ to the east. With these adjustments to the original export production estimate applied, the basinwide average increases to $\sim 60 \mathrm{~g} \mathrm{C} \mathrm{m}^{-2} \mathrm{yr}^{-1}$. This is at the upper limit of export production estimated from in situ nitrate drawdown (Henson et al. 2003, Sanders et al. 2005, Waniek et al. 2005), but still lower than the estimates from export algorithms applied to satellite-derived total production (Falkowski et al. 1998, Laws et al. 2000).

Non-siliceous plankton contribute additional export production after silica has become depleted, but what is their contribution to export production whilst diatoms still dominate the species composition? Nutrientreplete diatoms are expected to consume silica and nitrate at a 1:1 ratio (Brzezinski et al. 1998), although this may vary with the species of diatom and light conditions (Brzezinski 1985). The total silica and nitrate, as estimated from the satellite-derived nutrient concentrations, drawn down for the period between the initition of the bloom and the time when silica becomes depleted was calculated. In the west of the region, the $\mathrm{Si}: \mathrm{N}$ ratio for this period was $\sim 0.8$, indicating that more nitrate than silica is consumed. This suggests that nonsiliceous plankton are also consuming nitrate and thus contributing to export production. Approximately $30 \%$ more nitrate than silica is consumed, suggesting that diatoms are responsible for $\sim 70 \%$ of export production during the period when they dominate the community composition. To an annual total export production of $\sim 65 \mathrm{~g} \mathrm{C} \mathrm{m}^{-2} \mathrm{yr}^{-1}$, diatoms thus contribute $\sim 40 \mathrm{~g} \mathrm{C} \mathrm{m}^{-2}$ $\mathrm{yr}^{-1}$ prior to silica depletion. Non-siliceous plankton must then contribute the remaining $\sim 25 \mathrm{~g} \mathrm{C} \mathrm{m}^{-2} \mathrm{yr}^{-1}$. Of this, $20 \mathrm{~g} \mathrm{C} \mathrm{m}^{-2} \mathrm{yr}^{-1}$ occurs prior to silica depletion and $5 \mathrm{~g} \mathrm{C} \mathrm{m}^{-2} \mathrm{yr}^{-1}$ occurs after silica depletion. To the east of the Reykjanes Ridge, the $\mathrm{Si}: \mathrm{N}$ ratio was $\sim 1$, and therefore diatoms are expected to be responsible for the vast majority of export prior to silica depletion. To an annual total export production of $\sim 45 \mathrm{~g} \mathrm{C} \mathrm{m}^{-2} \mathrm{yr}^{-1}$ diatoms are contributing $\sim 30 \mathrm{~g} \mathrm{C} \mathrm{m}^{-2} \mathrm{yr}^{-1}$ prior to silica depletion, whilst non-siliceous plankton contribute $\sim 15 \mathrm{~g} \mathrm{C} \mathrm{m}^{-2} \mathrm{yr}^{-1}$ after silica depletion. On average over the study area, diatoms contribute $\sim 65 \%$ of the annual export production in the Irminger Basin.

\section{CONCLUSIONS}

Nitrate, phosphate and silica concentration were estimated at high spatial and temporal resolution from satellite SST and chl $a$, allowing the timing of nutrient depletion to be assessed. Nitrate and phosphate did 
not become depleted during the Irminger Basin spring bloom. Silica became depleted to below the concentration at which diatoms are out-competed by nonsiliceous plankton. The timing of silica depletion, and hence the timing of the transition from diatom dominance of the species composition to dominance by nonsiliceous species, was estimated. A lower-boundary estimate of export production was made based on the total production between the initition of the bloom and the time of silica depletion. To the west of the Reykjanes Ridge the annual export production was estimated at $\sim 65 \mathrm{~g} \mathrm{C} \mathrm{m}^{-2} \mathrm{yr}^{-1}$, whilst to the east of the ridge the annual export production was lower at $\sim 45 \mathrm{~g} \mathrm{C} \mathrm{m}^{-2}$ $\mathrm{yr}^{-1}$. Estimates of the relative contributions to export production by diatoms and non-diatoms were made by consideration of the additional nitrate consumed after silica was depleted and the silica-to-nitrate drawdown ratio. Approximately $65 \%$ of the annual export production is contributed by diatoms. This method of estimating export production is suitable for regions where silica limits production and diatoms dominate export production.

Acknowledgements. Thanks to the captain and crew of the RRS 'Discovery' and all the scientists who took part in the 4 Marine Productivity cruises. The Marine Productivity thematic programme was funded by the Natural Environment Research Council, UK, and is a contribution to UK GLOBEC. SeaWiFS data were provided by GSFC/NASA in accord with the SeaWiFS Research Data Use Terms and Conditions Agreement. The AVHRR SST data were provided by the NASA EOSDIS, DAAC at Goddard Space Flight Center.

\section{LITERATURE CITED}

Astoreca R (2003) Phytoplankton production in the Irminger Basin, NE Atlantic, in summer and winter 2002. MSc thesis, University of Southampton, Southampton

Aufdenkampe AK, McCarthy JJ, Navarette C, Rodier M, Dunne J, Murray JW (2002) Biogeochemical controls on new production in the tropical Pacific. Deep-Sea Res II 49: 2619-2648

Backhaus JO, Hegseth EN, Wehde H, Irigoien X, Hatten K, Logemann K (2003) Convection and primary production in winter. Mar Ecol Prog Ser 251:1-14

Barbini R, Colao F, Fantoni R, Fiorani L, Okladnikova IG, Palucci A (2005) Lidar calibrated satellites sensed primary production in the southern ocean. J Optoelec Adv Mater 7: 1091-1101

Barlow RG, Mantoura RFC, Gough MA, Fileman TW (1993) Pigment signatures of the phytoplankton bloom composition in the Northeastern Atlantic during the 1990 spring bloom. Deep-Sea Res II 40:459-477

Behrenfeld MJ, Falkowski PG (1997a) Photosynthetic rates derived from satellite-based chlorophyll concentrations. Limnol Oceanogr 42:1-20

Behrenfeld MJ, Falkowski PG (1997b) A consumer's guide to phytoplankton primary productivity models. Limnol Oceanogr 42:1479-1491

Berger M, Camps A, Font J, Kerr Y and 9 others (2002) Mea- suring ocean salinity with ESA's SMOS mission. Bull Ecol Soc Am 111:113-121

Boye $\mathrm{M}$, Aldrich AP, van den Berg CMG, de Jong JTM, Veldhuis M, de Baar HJW (2003) Horizontal gradient of the chemical speciation of iron in surface waters of the northeast Atlantic Ocean. Mar Chem 80:129-143

Brierley A and researchers of the Marine Productivity cruise (2003) Cruise report: RRS Discovery cruise 264: biophysical studies of zooplankton dynamics in the northern North Atlantic: summer, 25 July-28 August 2002, Natural Enviromental Research Council, Swindon

Broecker WS, Peng TH (1982) Tracers in the sea. Columbia University/Lamont-Doherty Geological Observatory, Palisades, NY

Brown L, Sanders R, Savidge G, Lucas CH (2003) The uptake of silica during the spring bloom in the Northeast Atlantic Ocean. Limnol Oceanogr 48:1831-1845

Brzezinski MA (1985) The Si:C:N ratio of marine diatoms. Interspecific variability and the effect of some environmental variables. J Phycol 21:347-357

Brzezinski MA, Villareal TA, Lipschultz F (1998) Silica production and the contribution of diatoms to new and primary production in the central North Pacific. Mar Ecol Prog Ser 167:89-104

Campbell JW (1995) The lognormal distribution as a model for bio-optical variability in the sea. J Geophys Res C 100: 13237-13254

Campbell JW, Aarup T (1992) New production in the North Atlantic derived from seasonal patterns of surface chlorophyll. Deep-Sea Res I 39:1669-1694

Chavez FP, Service SK, Buttrey SE (1996) Temperature-nitrate relationships in the central and eastern tropical Pacific. J Geophys Res C 101:20553-20563

Conkright ME, Antonov JI, Baranova O, Boyer TP and 8 others (2002) World Ocean Atlas 2001, NOAA Atlas, NESDIS 42. US Government Printing Office, Washington, DC

Dugdale RC, Goering JJ (1967) Uptake of new and regenerated forms of nitrogen in primary productivity. Limnol Oceanogr 12:196-206

Dugdale RC, Wilkerson FP (1998) Silicate regulation of new production in the equatorial Pacific upwelling. Nature 391:270-273

Dugdale RC, Wilkerson FP, Minas HJ (1995) The role of a silicate pump in driving new production. Deep-Sea Res I 42:697-719

Egge JK, Aksnes DL (1992) Silicate as regulating nutrient in phytoplankton competition. Mar Ecol Prog Ser 83:281-289

Eppley RW, Peterson BJ (1979) Particulate organic matter flux and planktonic new production in the deep ocean. Nature 282:677-680

Falkowski PG, Barber RT, Smetacek V (1998) Biogeochemical controls and feedbacks on ocean primary production. Science 281:200-206

Falkowski PG, Scholes RJ, Boyle E, Canadell J and 13 others (2000) The global carbon cycle: a test of our knowledge of earth as a system. Science 290:291-296

Fasham M (2003) Ocean biogeochemistry: the role of the ocean carbon cycle in global change. Springer-Verlag, Berlin

Furnas MJ (1990) In situ growth rates of marine phytoplankton: approaches to measurement, community and species growth rate. J Plankton Res 12:1117-1151

Garside C, Garside JC (1993) The $f$-ratio on 20 degrees W during the North Atlantic Bloom Experiment. Deep-Sea Res 40:75-90

Goes JI, Saino T, Oaku H, Jiang DL (1999) A method for estimating sea surface nitrate concentrations from remotely 
sensed SST and chlorophyll a-a case study for the North Pacific Ocean using OCTS/ADEOS data. IEEE (Inst Elect Electron Eng) Trans Geosci Remote Sens 37:1633-1644

Goes JI, Saino T, Oaku H, Ishizaka J, Wong CS, Nojiri Y (2000) Basin scale estimates of sea surface nitrate and new production from remotely sensed sea surface temperature and chlorophyll. Geophys Res Lett 27:1263-1266

Gregg WW, Ginoux P, Schopf PS, Casey NW (2003) Phytoplankton and iron: validation of a global three-dimensional ocean biogeochemical model. Deep-Sea Res II 50: 3143-3169

Henson SA, Sanders R, Allen JT, Robinson IS, Brown L (2003) Seasonal constraints on the estimation of new production from space using temperature-nitrate relationships. Geophys Res Lett 30:1912; doi:1910.1029/2003GL017982

Hooker SB, McClain CR (2000) The calibration and validation of SeaWiFS data. Prog Oceanogr 45:427-465

Huisman J, Van Oostveen P, Weissing FJ (1999) Critical depth and critical turbulence: two different mechanisms for the development of phytoplankton blooms. Limnol Oceanogr 44:1781-1787

Jeffrey SW, Humphrey GF (1975) New spectrophotometric equation for determining chlorophyll $a, b c 1$ and $c 2$. Biochem Physiol Pflanz (BPP) 167:191-204

Kamykowski D, Zentara SJ, Morrison JM, Switzer AC (2002) Dynamic global patterns of nitrate, phosphate, silicate and iron availability and phytoplankton community composition from remote sensing data. Global Biogeochem Cycles 16:1077, doi:1010.1029/2001GB001640

Kirkwood DC (1995) The SanPlus segmented flow autoanalyser and its application. Scalar Analytical BV Publications, Breda

Koeve W (2001) Wintertime nutrients in the North Atlanticnew approaches and implications for new production estimates. Mar Chem 74:245-260

Kovala PE, Larrance JD (1966) Computation of phytoplankton cell numbers, cell volume, cell surface and plasma volume, per metre, from microscopic counts. University of Washington Department of Oceanography Special Reports No. 38. University of Washington, Seattle, WA

Laws EA, Falkowski PG, Smith WO Jr, Ducklow H, McCarthy JJ (2000) Temperature effects on export production in the open ocean. Global Biogeochem Cycles 14:1231-1246

Longhurst A (1998) Ecological geography of the sea. Academic Press, San Diego, CA

Martin JH, Fitzwater SE, Gordon RM, Hunter CM, Tanner SJ (1993) Iron, primary production and carbon-nitrogen flux studies during the JGOFS North Atlantic Bloom Experiment. Deep-Sea Res II 40:115-134

Menden-Deuer S, Lessard EJ (2000) Carbon to volume relationships for dinoflagellates, diatoms, and other protist plankton. Limnol Oceanogr 45:569-579

Minas HJ, Minas M (1992) Net community production in high nutrient low chlorophyll waters of the tropical and Antarctic oceans: grazing vs iron hypothesis. Oceanol Acta 15: 145-162

Mitchell BG (1992) Predictive bio-optical relationships for polar oceans and marginal ice zones. J Mar Syst 3:91-105

Moore JK, Doney SC, Lindsay K (2004) Upper ocean ecosystem dynamics and iron cycling in a global three-dimensional model. Global Biogeochem Cycles 18:GB4028, doi: 4010.1029/2004GB002220

Editorial responsibility: Otto Kinne (Editor-in-Chief), Oldendorf/Luhe, Germany
Neuer S, Davenport R, Freudenthal T, Wefer G, Llinas O, Rueda MJ, Steinberg DK, Karl DM (2002) Differences in the biological carbon pump at three subtropical ocean sites. Geophys Res Lett 29:1885

Parslow JS, Boyd PW, Rintoul SR, Griffiths FB (2001) A persistent sub-surface chlorophyll maximum in the Interpolar Frontal Zone south of Australia: seasonal progression and implications for phytoplankton-light-nutrient interactions. J Geophys Res C 106:31543-31557

Pondaven P, Ruiz-Pino D, Druon JN, Fravalo C, Treguer P (1999) Factors controlling silicon and nitrogen biogeochemical cycles in high nutrient, low chlorophyll systems (the Southern Ocean and the North Pacific): comparison with a mesotrophic system (the North Atlantic). Deep-Sea Res I 46:1923-1968

Redfield AC, Ketchum BH, Pritchard FA (1963) The influence of organisms on the composition of seawater. In: Hill $\mathrm{N}$ (ed) The sea, Vol 2. Interscience, New York, p 26-77

Sanders R, Jickells T (2000) Total organic nutrients in Drake Passage. Deep-Sea Res 47:997-1014

Sanders R, Brown L, Henson SA, Lucas MI (2005) New production in the Irminger Basin during 2002. J Mar Syst 55: 291-310

Sathyendranath S, Platt T, Horne EPW, Harrison WG, Ulloa O, Outerbridge R, Hoepffner N (1991) Estimation of new production in the ocean by compound remote sensing. Nature 353:129-133

Savidge G, Turner DR, Burkill PH, Watson AJ, Angel MV, Pingree RD, Leach H, Richards KJ (1992) The BOFS 1990 spring bloom experiment: temporal evolution and spatial variability of the hydrographic field. Prog Oceanogr 29: 235-281

Savidge G, Boyd P, Pomroy A, Harbour D, Joint I (1995) Phytoplankton production and biomass estimates in the northeast Atlantic Ocean, May to June 1990. Deep-Sea Res I 42:599-617

Schlitzer R (2002) Carbon export fluxes in the Southern Ocean: results from inverse modelling and comparison with satellite-based estimates. Deep-Sea Res II 49:1623-1644

Siegel DA, Doney SC, Yoder JA (2002) The North Atlantic spring phytoplankton bloom and Sverdrup's critical depth hypothesis. Science 296:730-733

Strathmann RR (1967) Estimating the organic carbon content of phytoplankton from cell volume or plasma volume. Limnol Oceanogr 12:411-418

Syrett PJ (1981) Nitrogen metabolism of microalgae. Can Bull Fish Aquat Sci 210:182-210

Tungaraza C, Rousseau V, Brion N, Lancelot C, Gichucki J, Baeyens W, Goeyens L (2003) Contrasting nitrogen uptake by diatoms and Phaeocystis-dominated phytoplankton assemblages in the North Sea. J Exp Mar Biol Ecol 292: $19-41$

Tyrell T (1999) The relative influences of nitrogen and phosphorus on oceanic primary production. Nature 400: $525-531$

Waniek JJ, Holliday NP, Davidson R, Brown L, Henson SA (2005) The importance of freshwater in controlling the onset and species composition of the Greenland Shelf spring bloom. Mar Ecol Prog Ser 288:45-57

Wheeler PA, Kokkinakis SA (1990) Ammonium recycling limits nitrate use in the oceanic sub-Arctic Pacific. Limnol Oceanogr 35:1267-1278

Submitted: July 7, 2005; Accepted: October 11, 2005

Proofs received from author(s): April 11, 2006 